\title{
EVALUATION OF THE POSSIBILITY OF USING METHANE FROM CNG BY POTENTIAL MOTOR VEHICLE USERS
}

doi: 10.2478/cqpi-2019-0078

Date of submission of the article to the Editor: 14/04/2019

Date of acceptance of the article by the Editor: 21/05/2019

\author{
Adam Górniak ${ }^{1}$ \\ Katarzyna Midor ${ }^{2}$ - orcid id: 0000-0001-5680-7354 \\ Kaźmierczak Jan² - orcid id: 0000-0001-5843-2016 \\ 1 Adam Górniak Firma Konsultingowa, Poland \\ 2 Silesian University of Technology, Poland
}

\begin{abstract}
Today's world is facing the necessity of reducing air pollution. One of the alternatives is to limit pollution related to road transport by using CNG fuel.

The European Union is imposing increasingly strict requirements regarding the cleanness of car fumes, and the Polish government is endeavouring to take actions aimed at reducing the pollution related to car use by planning the development of transport electromobility. In this article, the authors want to draw attention to methane as an alternative to traditional fuels.

The article presents the results of a survey conducted among drivers, which regarded their readiness to use CNG-powered cars. The results indicate that while respondents appreciate the ecological value of this fuel, they are also worried about safety, which is contradicted by the analysis of CNG advantages and disadvantages.
\end{abstract}

Keywords: CNG fuel, evaluation of CNG benefits, air pollution

\section{INTRODUCTION}

The contemporary world faces the problem of ever-increasing air pollution, the source of which is among other road transport. This is particularly visible in Poland, where the level of benzopyrene concentration is observed to be the highest in Europe - more than $1.5 \mathrm{ng} / \mathrm{m} 3$ (Plan rozwoju, 2016), (Górniak and Kaźmierczak, 2017). To counteract the deterioration of air condition, the European Union is imposing increasingly strict requirements regarding the cleanness of car fumes, and the Polish government is endeavouring to take actions aimed at reducing the pollution related to car use by planning the development of transport electromobility (Kaźmierczak, ed al., 2018), (Rozporządzenie, 2007), (Duncan, 2016). In view of these facts, the authors of the article would like to draw attention to methane as an alternative to traditional fuels. Methane in the automotive industry is used in the form of CNG (Compressed Natural Gas) or LNG (Liquid Natural Gas) (Wawrzynowicz and Brzeziński, 2017), (Kardasz, et al, 2008), (Żółtowski, 2003), (Sochaczewski, 2015) (Ulewicz, 2018b) (Ulewicz, 2018a). 
A comparison of methane and petroleum fuels indicates that methane is much cleaner, but requires far greater precautions to be taken during the use, e.g. its use requires an appropriate fuel cylinder or more frequent technical inspections of the fuel system. However, when the safety requirements are fulfilled, it compares favourably with traditional car fuels.

A summary of data regarding the benefits and drawbacks of methane as a fuel, which has been presented in Table 1, allows concluding as follows: it is a fuel that meets the requirements of safety, environmental protection, availability of resources better than fuels based on petroleum compounds.

The use of methane as a car fuel on a large scale requires a much larger number of fuel stations and a lower price of the LPG system installation in cars. It is probably this factor that to the largest extent discourages potential customers from using the gaseous fuel. However, bearing in mind the experiences related to the launch of LPG fuel on a large scale, such problems can also be solvedin this case (Dual Fuel System, 2013), (Stelmasiak, 2006), (Wawrzynowicz and Brzeziński, 2017), (Kaźmierczak et al., 2018), (Spałek, 2019), (Orzechowska et al, 2014), (Iwanicki, 2014).

Table 1

Summary of benefits and drawbacks of methane-based gaseous fuel

\begin{tabular}{|l|l|l|l|l|l|}
\hline Category & Ecology & $\begin{array}{l}\text { Availability } \\
\text { of resources }\end{array}$ & Safety & Usage & Operation \\
\hline classification & & $\checkmark$ & & & \\
\hline key issue & $\begin{array}{l}\text { clean } \\
\text { fumes }\end{array}$ & $\begin{array}{l}\text { own } \\
\text { deposits, } \\
\text { diversificatio } \\
\text { n of sources }\end{array}$ & $\begin{array}{l}\text { less } \\
\text { explosive }\end{array}$ & $\begin{array}{l}\text { small number of } \\
\text { fuel stations } \\
\text { high price of } \\
\text { LPG conversion } \\
\text { in the car }\end{array}$ & $\begin{array}{l}\text { better engine } \\
\text { efficiency }\end{array}$ \\
\hline
\end{tabular}

Source: (Kaźmierczak ed al., 2018)

In view of the above, if a problem related to the use of CNG is an insufficient number of fuel stations and a high price of LPG conversion in the car, it seems advisable to evaluate how this fuel recipients are prepared and willing to use it. To find out what the drivers' real views on the possibility of using CNG are, a survey among potential users of this fuel was conducted

\section{INVESTIGATIONS INTO THE POSSIBILITY OF USING CNG BY DRIVERS}

A survey among potential users of CNG was conducted on a group of drivers customers of the Voivodeship Training Centre for Drivers in Katowice, in the first quarter of 2018. The survey included 254 drivers, who were asked about their opinion on using CNG as a fuel for passenger cars and commercial vehicles (Górniak, 2019).

The survey consisted of 9 questions, which have been listed below:

- How are you feeling today?

- Are you familiar with the concept of CNG-powered cars?

- Do you drive a car on a regular basis?

- Do you use public transport on a regular basis?

- Would you be ready to take part in a test drive in a car powered by compressed natural gas (CNG)?

- Would you be ready to drive a CNG-powered car on a regular basis? 
- Could you, please, quote one reason why you would become interested in a CNGpowered car?

- What concerns do you have about using a CNG-powered car?

- Can you see the possibility of using natural gas to supply?

Respondents in questions 2 to 6 had the opportunity to answer "yes" or "no". In the remaining questions, they marked selected answers from the list.

\subsection{Description of the survey results}

The survey questionnaire was completed by a total of 254 people. Its results have been presented and discussed below:

Question 2 is a general question about being familiar with the concept of CNG-powered cars. Its aim is to form an opinion about the reality of further answers, i.e. to find whether the choice of a particular answer is supported by concrete knowledge or whether it is based solely on suppositions. Their knowledge about the concept of methane-powered cars was confirmed by $78 \%$ of the surveyed.

Question 3 concerns the respondent's acquaintance with the principles of using motor vehicles and the manner he/she participates in road traffic. This question indicates whether he/she knows issues related to the use of various fuels or whether it does not matter for them. In their replies, $64 \%$ of the surveyed admitted that they regularly used cars as drivers.

Question 4 is aimed at defining in what way the surveyed participate in road traffic. In reply to this question, $38 \%$ of the respondents admitted they regularly used public transport. Taking into consideration the results of question 3 , it can be concluded that approximately $26 \%$ of the respondents regularly drive a car and, at the same time, they are users of public transport.

Questions 5 and 6 open a group of questions that directly concern issues related to using CNG-powered cars. Questions 5 and 6 should be considered together, as they concern the respondents' readiness to take part in a test drive and use a CNG-powered car on a regular basis. In the case of question 5 (Would you be ready to take part in a test drive in a CNG-powered car?), $67 \%$ of the respondents answered yes, $31 \%-$ no, and $2 \%$ did not give a reply. In the case of question 6 (Would you be ready to drive a CNG-powered car on a regular basis?), 56\% answered yes, $40 \%$ gave a "no" answer, and $3 \%$ did not reply. It can be concluded that the surveyed declared their willingness to take part in a test drive, but they were more cautious about using a CNG-powered car on a regular basis. There is a visible 10\% drop in "yes" answers. Questions 5 and 6 check whether the surveyed are ready for a change of fuel and should be considered together with question 1.

Two subsequent survey questions, 7 and 8 , concern the potential needs of the users of CNG-powered car. Question number 7 (Could you, please, quote a reason why you would become interested in a CNG-powered car) - Fig. 1, provides a surveyed person with a possibility of choosing one of eight answers. The most frequently chosen reply $30 \%$ is c (A lower travel cost compared to a petrol-powered system), followed by answer $b-18 \%$ (Care for the environment). The least significant for the surveyed was answer $f-1 \%$ (Possibility of filling up with fuel on one's own at home from the municipal supply network). Such a choice is inconsistent with the strongest preference of the respondents, i.e. lowering the cost of fuel, as pumping fuel at their houses enables drivers to become independent from the agency of fuel stations. 
We can probably talk about a potential user's need that he/she does not realize yet, as large-scale methods of pumping fuel on one's own do not exist in Poland, apart from fuel stations, which serve this purpose. If this direction of development was chosen, it would entail the necessity to take actions aimed at informing and increasing the awareness of the society.

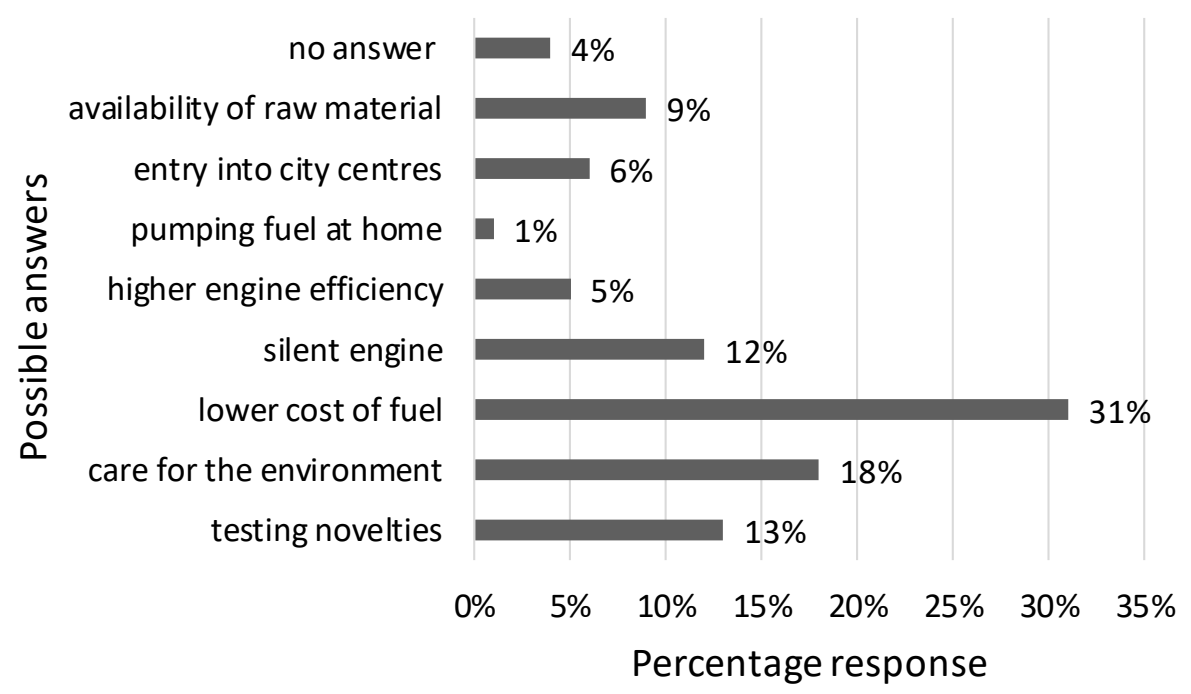

Fig. 1. Declared reasons for interest in a CNG-powered car

Answers to question 8, regarding concerns related to the use of a CNG-powered car, have been presented in Fig. 2. It can also be assumed that some of the unconscious needs are expressed in this way. The most frequently chosen reply was answer a $23 \%$ "I don't feel safe due to cylinders with compressed gas installed in the car. The second frequent answer regarding the respondents' concerns was answer e - 19\% "risk of explosion during a collision". The third place in terms of percentage share - $14 \%$ belongs to answer c "I am afraid that I would have to go out of my way to fill up with fuel", and the fourth place to answer $b-10 \%$ "I am afraid that I would not know where CNG fuel stations are located". It can therefore be seen that the major concerns are connected with safety $-42 \%$, followed by availability of fuel stations $-24 \%$. Concerns related to decreased power of the engine, installation or repair of the tank are marginal.

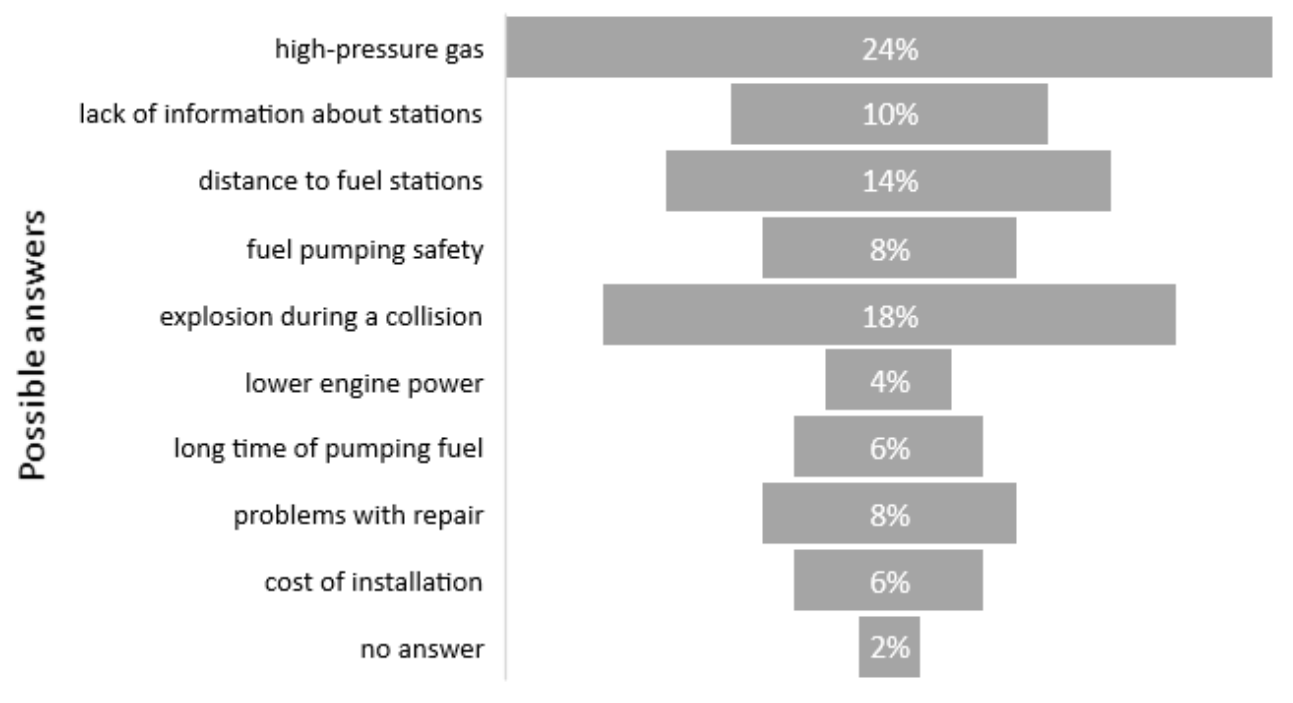

Fig. 2. Declared concerns about the use of a CNG-powered car 
Question 9 has a double meaning - it directly addresses people using the means of transport quoted in it and, on the other hand, broadens the horizon of analysis for individuals already interested in the use of CNG by adding issues that do not concern it directly. The results have been given in Fig. 3. Most of the respondents - as many as $63 \%$ - chose answer a "city buses".

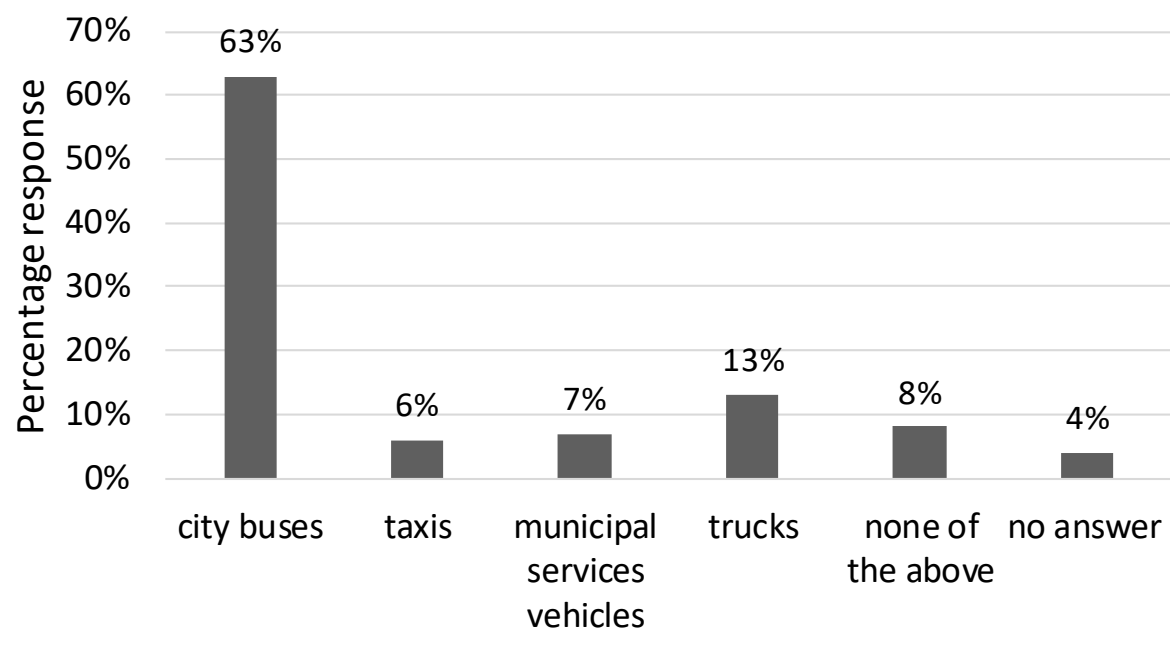

Possible answers

Fig. 3. Proposals of using CNG for another type of vehicles

At the end of the article, the respondent's well-being in the context of other answers will be discussed.

Question 1 is a question about well-being, and, strictly speaking, about the attitude. Its results are presented in Fig. 4 . The choice of answer a or b (a total of $23 \%$ ) may indicate a respondent's reluctant attitude towards changes on the day when the survey was conducted. Choosing answer c or d (a total of $75 \%$ ) may point to an attitude that is open to changes.

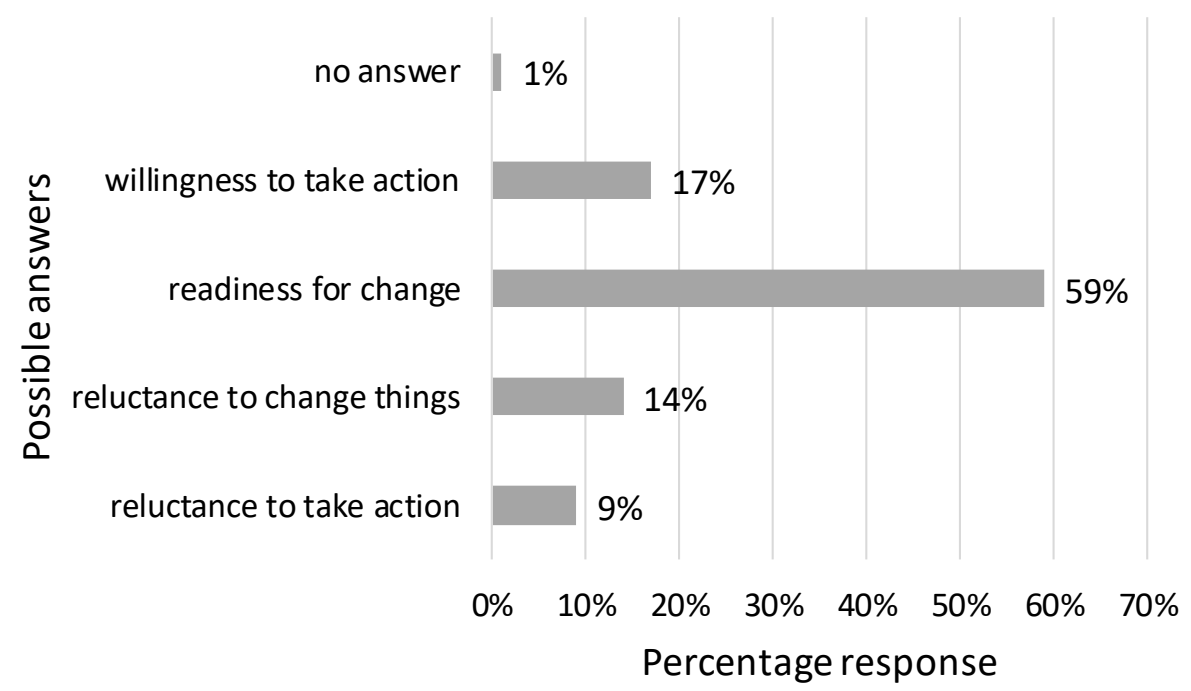

Fig. 4. Chart of the respondents' readiness for change 
The correlation of the answer to question 1 (How are you feeling today?) with the answer to question 5 (Would you be ready to take part in a test drive in a CNG-powered car?) and question 6 (Would you be ready to drive a CNG-powered car on a regular basis?) shows that the respondent's well-being on the day of the survey was correlated with their evaluation of the possibility of using CNG. Nearly $80 \%$ of the surveyed with open-minded attitudes were ready to participate in a test drive in a CNG-powered car, and approximately $70 \%$ were ready to drive such a car on a regular basis. On the other hand, most of the close-minded respondents did not want to take part in a test drive in a CNG-powered car, let alone drive it on a regular basis. Such a strong relationship suggests that there will always be a group of people reluctant to accept novelties due to their personal attitude to life at a given moment. It is supposed that irrespective of a technical solution, this phenomenon occurs not only in the case of the CNG system, but has a more general character. In this study it was observed for approximately $20 \%$ of the surveyed.

\section{CONCLUSION}

Summarising the results of the questionnaire, we can draw the following conclusions:

- the concept of CNG-powered cars is familiar to drivers, there were two thirds of positive answers,

- more than a half of the respondents say they would drive a CNG-powered car on a regular basis,

- the most important factor that has an impact on the driver's decision to switch to CNG is the reduced fuel cost,

- the greatest concerns about the use of CNG are those related to safety due to high gas pressure,

- the preferred use of CNG in cars other than private is city buses,

- the respondent's well-being (mood) is correlated to the choice of the questionnaire answer.

Moreover, it should be emphasized that the needs of users, i.e. consumers, cannot be effectively identified by merely asking them if they are for or against the proposed product. A clear correlation between the respondent's readiness to try CNG and their well-being indicates that it is necessary to improve the manner of conducting a survey so as to better reflect at which stage of customer journey the respondent is. The range of questions in the questionnaire analysis could be extended with other aspects, such as e.g. attitude to ecology, wealth or car use intensity.

These conclusions are not consistent with the results of a theoretical analysis of CNG benefits and drawbacks presented in Table 1. The respondents appreciate the ecological value of this fuel, but are concerned about safety, which contradicts the analysis of CNG benefits and drawbacks. On the other hand, the poorly-developed network of fuel stations or the high price of the CNG system, which was classified as a major drawback in the theoretical analysis of benefits and drawbacks, did not raise any fears of the surveyed.

\section{REFERENCES}

Dual Fuel System LTD, 2013. Fuel Fusion. s.I. : Dual Fuel System LTD.

Duncan, E., 2016. Creating value through transforming customer journeys. Customer experience. Winter, 1. 
Górniak, A., (2019). Wykorzystanie wybranych środków i sposobów pozyskiwania $i$ przetwarzania danych dla potrzeb wyprzedzającego planowania jakości z uwzględnieniem potrzeb klienta, jako elementu przygotowania produkcji na przykładzie wybranej branży. Praca doktorska, Zabrze, Politechnika Śląska.

Górniak, A., Każmierczak, J., (2017). Problematyka wyprzedzającego planowania jakości wyrobu i procesu na przykładzie branży automotiv. XX Konferencja Innowacje w Zarządzaniu i Inżynierii Produkcji, Zakopane.

Iwanicki, J., 2014. Feasibility analysis of the application of compressed natural gas as a fuel for compression-ignition engines. Journal of Mechanical and Transport Engineering, 66(4), 31-39.

Kardasz, A., Dniestrzański, P. \& Michałowski, R., 2008. Rozwój sieci CNG jako czynnik kreowania popytu. Rynek Energii, 4, pp.37-44.

Kaźmierczak, J., Midor, K., Górniak, A., 2018. Advantages and disadvantages of using methane from cng in motor vehicles in polish conditions. Multidisciplinary Aspects of Production Engineering - MAPE. Zawiercie, Panova, 1.

Orzechowska, M., Szurlej, A. \& Filip, M., 2014. Economic and environmental aspects of using CNG in urban public transport - based on the experience of MPK Rzeszów. Logistyka, 4, 4756-4763. Available at:

http://yadda.icm.edu.pl/baztech/element/bwmeta1.element.baztech-605675c2-

3dc2-49a0-82cf-df1 c34726a2d?q=413ad7e2-8f82-4b3e-88ff-

$75 f c 6 d 1$ ae625 $\$ 10 \& q t=I N \_P A G E$.

Plan Rozwoju Elektromobilności, (2016). Ministerstwo Energetyki.

Rozporządzenie (WE) nr 715/2007 Parlamentu Europejskiego i Rady z dnia 20 czerwca 2007.

Sochaczewski, R., 2015. CNG injector bench tests of a direct injection system. Combustion Engines.

Spałek, S., 2019. Data Analytics in Project Management. Boca Raton, FL : CRC Press/Taylor \& Francis Group, 2019. ISBN 978-1-138-30728-5.

Stelmasiak, Z., 2006. Wybrane problemy stosowania gazu ziemnego do zasilania silników o zapłonie samoczynnym. Archiwum Motoryzacji, 1.

Ulewicz, R., 2013a. Effectiveness assessment of functioning o $38 \mathrm{f}$ quality assurance system. Production Engineering Archives, 1(1), 38-40. Available at: http://www.qpij.pl/vol-1-no-1-2013-production-engineering-archivespage/menu_id/209.

Ulewicz, R., 2018b. Outsorcing quality control in the automotive industry. MATEC Web of Conferences, 183, 03001. Available at: https://doi.org/10.1051\%2Fmatecconf\%2F201818303001.

Wawrzynowicz, A., Brzeziński, T., 2017. Gazownictwo wobec ustawy o elektromobilnosci i paliwach alternatywnych. Przegląd Gazowniczy, 6.

Żółtowski, A., 2003. Unlimited emission from engines fueled with CNG. Journal of KONES, 10(3-4), 413-418. Available at: http://ilot.edu.pl/KONES/2003/3-4/49.pdf. 